\title{
Associações entre os fenótipos ABO, RhD, mutações da proteína Duffy e a malária vivax em habitantes do estado do Amazonas, Brasil
}

\section{Associations of the ABO blood group, Rh antigen and Duffy protein mutations with vivax malaria in inhabitants of the Amazonas State, Brazil}

Sérgio Roberto L. Albuquerque

Orientadora: Maria Cristina dos Santos

\section{Resumo}

Neste estudo investigamos associações entre o sistema sanguíneo $\mathrm{ABO}$, antígeno $\mathrm{RhD}$, as mutações da proteína Duffy $\left(125 \mathrm{G}>\mathrm{A}(F Y A / F Y B) 265 \mathrm{C}>\mathrm{T}\right.$ e $298 \mathrm{G}>\mathrm{A}\left(\right.$ antígeno $\left.\mathrm{Fy}^{\mathrm{X}}\right)$ e do promotor GATA box, $-33(\mathrm{~T}>\mathrm{C})$,) e a malária vivax, em habitantes do estado do Amazonas, Brasil, uma área endêmica de malária. A identificação do $P$. vivax, assim como a verificação das densidades parasitárias, foi determinada por testes microscópicos e avaliações clínicas de 497 pacientes infectados com malária vivax. Nestes pacientes foram realizadas também fenotipagens do sistema $\mathrm{ABO}$, antígeno RhD e sistema Duffy, assim como as genotipagens do sistema sanguíneo Duffy por PCR/RFLP. Os resultados encontrados foram comparados com dados publicados das mesmas variáveis em um grupo de doadores de sangue da Amazônia brasileira, sem antecedentes de malária. Nossos dados mostraram, que a presença do antígeno A, genótipos $F Y A / F Y B-33$ e $F Y B / F Y B-33$, poderia ser uma vantagem seletiva na população, reduzindo a taxa de infecção pelo $P$. vivax nesta região, porém sem estarem associados ao nível de densidade parasitária das infecções de malária. Não encontramos associação entre o antígeno $\mathrm{RhD}$ e a susceptibilidade ao $P$. vivax, no entanto os genótipos $F Y A / F Y B, F Y A / F Y A$ mostraram-se associados ao aumento da taxa de infecção pelo $P$. vivax na região estudada. Os genótipos $F Y B / F Y X$ e $F Y A / F Y X$ não se mostraram associados à taxa de infecção pelo $P$. vivax, mas sim aos baixos níveis de densidades parasitárias encontradas entre os pacientes infectados com este genótipo. Relatamos, ainda, neste estudo, indivíduos com o genótipo FYB-33/FYB-33 com antecedentes de malária vivax. Estes resultados sugerem que, em regiões endêmicas de malária, pode estar havendo adaptações naturais tanto quanto ao surgimento de mecanismos parciais de defesa contra o Plasmodium vivax distintos dos já descritos em descendentes africanos como adaptações que podem estar também levando a um aumento à susceptibilidade a este tipo de malária.

Palavras-chave: Malária; Plasmodium vivax; ABO; Rh; Duffy; grupos sanguíneos.

Resumo de dissertação apresentada ao Programa de Pós-Gradução em Biotecnologia-PPGBIOTEC, da Universidade Federal do Amazonas-Ufam para obtenção do título de Doutor.

Área de concentração: Imuno-hematologia.

Correspondência: Sérgio Roberto Lopes Albuquerque

Rua Lindon Johnson, 55, Res. Atlantis, casa 16, Parque Dez

69054-712 - Manaus-AM - Brasil

E-mail:sergio.rla@ig.com.br

\begin{abstract}
In this study we investigated the associations between the ABO blood groups, RhD antigen and Duffy protein mutations [125 G>A $(F Y A / F Y B), 265 \mathrm{C}>\mathrm{T}, 298 \mathrm{G}>\mathrm{A}\left(\mathrm{Fy}^{\mathrm{x}}\right.$ antigen) and the GATA box mutation $-33(\mathrm{~T}>\mathrm{C})$ ] with vivax malaria in inhabitants of the state of Amazonas, Brazil, an endemic area for malaria. Identification of Plasmodium vivax and the measurement of parasitemia were achieved by standard screening tests and clinical evaluations of 497 patients in which ABO, RhD and Duffy phenotyping was performed, as was Duffy blood group genotyping using PCR/RFLP reactions. These results were compared with previously published data of the same variables in blood donors from the Brazilian Amazon without any history of malaria. Our data show that the presence of the A antigen and $F Y A / F Y B-33$ and $F Y B / F Y B-33$ genotypes in the population may give a selective advantage, thereby reducing the $P$. vivax infection rate in this region, however without association with the parasite load of vivax malaria infection. We did not find associations between the $\mathrm{RhD}$ antigen and $P$. vivax susceptibility however the presence of the $F Y A / F Y B$ and $F Y A / F Y A$ genotypes proved to be associated with an increase in the $P$. vivax infection rate in this region. The $F Y B / F Y X$ and $F Y A / F Y X$ genotypes did not have any association with the $P$. vivax infection rate, but they proved to be associated with low parasite loads found among infected patients with these genotypes. In this study we identified only two $F Y B-33 / F Y B-33$ individuals with histories of malaria vivax. These results suggest that natural adaptation in malaria endemic regions may lead to the emergence of partial defense mechanisms against $P$. vivax different to those already described in Africans descendents, and additionally, other adaptations may increase the susceptibility to this type of malaria.
\end{abstract}

Key words: Malaria; Plasmodium vivax; ABO; Rh; Duffy; Blood groups.

Suporte Financeiro: Fundação de Apoio à Pesquisa do Estado do Amazonas - Fapeam.

Avaliação: A RBHH publica os resumos e abstracts de teses da área apresentados em entidades que tenham programas de pós-graduação reconhecidos pelo $\mathrm{MEC} / \mathrm{Capes}$ e considera a obtenção do título suficiente para sua publicação na forma como se propõe a seção.

Recebido: 11/02/2009

Aceito: 13/02/2009 